\title{
HIV/AIDS Spread among Rural Farmers in Nigeria: Implication on Village Agricultural Extension Service Delivery.
}

\author{
O. J. Saliu (Corresponding author) \& S.O. Adejoh \\ Department of Agricultural Economics and Extension \\ Faculty of Agriculture Kogi State University, Anyigba, Nigeria \\ Tel: 807-721-0049 E-mail: josaliu@yahoo.com. \\ C.O Orisagbemi \\ Department Of Food, Nutrition and Home Sciences Kogi \\ State University, Anyigba Nigeria
}

\begin{abstract}
There is a great public concern on the prevalence and effects of Human Immunes Virus (HIV) and Acquired Immune Deficiency Syndrome (AIDS) on the rural farmers and agricultural productivity in Nigeria. This study evaluated the implication of this disease on extension services, using Dekina LGA as its focus. It identified the level of HIV/AIDS prevalence by collecting secondary data on rate of HIV/AIDS infection from year 2000 to 2005 from medical centers in the study area. The study also examined farmers' perception on HIV/AIDS using mean scores from 5 point Likert scale in which, one hundred and sixty contact farmers were interviewed. Farmers had the highest HIV/AIDS infection record with 50.6 percent and 8.19 in year 2001 and 2005 respectively. While estimated farmers HIV/AIDS infection by 2010 would be 1,972. Findings also show that HIV/AIDS has negative effect on farmers health (mean score of 3.88), while 4.13 showed that respondents favoured the statement that "stigmatization and the scaring nature of AIDS prevented them from going for HIV/AIDS test. About 20 percent the extension workers claimed that infected farmers negatively affected their extension work delivery in some ways. This study therefore recommends that every village should be provided with comprehensive health clinic that would offer free HIV/AIDS treatment while capacity building for agricultural extension agents that will disseminate information on HIV/AIDS to farmers be put in place. Team work approach among rural development agencies concerned with provision of rural, community social services should also be encouraged.
\end{abstract}

Keywords: HIV/AIDS disease, Rural communities, Farmers and extension service

\section{Introduction}

Agriculture remains the largest non-oil export earner and the largest employer of labour accounting for 88 percent of non-oil foreign exchange earnings and 70 percent of the active labour force of the Nigerian population. Despite the low per capital output, technical in-efficiency and low nutritive value per hectare of food produced by farmers, Ijere (1992), the contribution of the agricultural sector to the Gross Domestic Product (GDP) still represented 35.9 percent and 34.6 percent in 2002 and 2003 respectively, (Bango 2005).

However, several studies have shown that Nigeria's food production in the aggregate has been growing at about $2.5 \%$ per annum in recent years and food demand has been growing at a rate of more than $3.5 \%$ per annum. The gap between the inadequate food supply and demand may further widen if the health of the smallholder farmers who produce about 90 percent of the nation's food and fibre are in danger (Okoro 1987). This is because the quality and quantity of labour supply is highly dependent on the state of their health (Umeh 1999). It implies that labour force of the rural communities is most likely going to be negatively affected in the event of any outbreak of a disease.

In essence, an outbreak of HIV/AIDS in a community could result in inefficiency in the optimum utilization of labour/inputs and as such a decrease in output (Anaeto, Nnadi, Ukpongson, Ugwuoke and Oforka; 2008). HIV/AIDS that was initially seen as urban problem is rapidly moving into the rural communities, (BNARDA, 2003). At the end of 1999, cases of HIV infections have been diagnosed and reported in all the 774 local government areas of the country, cutting across all the social strata of the society. The rapid transmission moved from near zero prevalence in 1990 to $5.8 \%$ among the adult population (15 - 49 years) in the year 2001 . With an 
estimate of 3.5 million cases in Nigeria, the country now ranks second in sub Sahara Africa and fourth in the world. Nigeria, as at 2002, had the highest number of AIDS orphans in the world. It has been estimated that the number of HIV/AIDS orphans in Nigeria has increased to 1.97 million by 2005 and would be 4.2 million by 2015 (NIMR 2003).

HIV/AIDS is mostly transmitted through unprotected sexual intercourse. The most vulnerable are people in the sexually active age. Incidentally, these groups are those in the agriculturally productive age. Food and Agriculture Organization (FAO, 2000) estimated that out of the 27 most affected countries in Africa, 7 million agricultural workers have died from AIDS and more deaths are likely in the next decades. The immediate and long run effect is unprecedented food crisis (FAO 1994). This is because HIV/AIDS is now a determining factor of food insecurity and livelihood incapacitation due to the growing evidences that the epidemic intensifies labour bottlenecks in agriculture, increases widespread malnutrition while causing significant increase in rural poverty and destitution in most affected countries (FAO, 2000 in Okoro, Ekwe, Nwaobiniu and Nwakor; 2009). HIV/AIDS is therefore undoubtedly the most important health and development problem that demand urgent attention and response especially if it is going to affect food production and sustenance of life in the rural communities where adequate access to comprehensive health facilities rarely exist.

Dekina Local Government Area of Kogi State in Nigeira is a typical rural community. It is equally dominated by farmers who have little access to health services and other information. It is therefore imperative to know, how the farmers in this community perceive HIV/AIDS disease. Specifically, what is the level of awareness? What is the level of prevalence among farmers of agriculturally productive age? How can we enhance HIV/AIDS free status among farmers in the rural communities? How does HIV/AIDS infection affect village extension service activities? Can the village extension agents render any assistance? Therefore the specific objectives of this study are to:

1. examine the attitude/perception of farmers on HIV/AIDS disease.

2. ascertain the trend of HIV/AIDS infections between years 2000 and 2005.

3. determine the rate of HIV/AIDS spread among farmers and other occupational groups in the study area.

4. predict the rate of HIV/AIDS spread in the next five years.

5. identify the effect of HIV/AIDS on rural agricultural extension work.

\section{Methodology}

\subsection{Study Area}

Dekina Local Government is the largest Local Government in Nigeria with a total land area of $7,691 \mathrm{~km}^{2}$ and a population of 260,312 which represents $9.61 \%$ of the total population of Kogi State according to 2006 population census in Nigeria. The local government is located on latitude $6.30^{\mathrm{oN}}$ and $7.30^{\mathrm{oN}}$ and longitude $7.00^{\mathrm{oE}}$ and $8.00^{\circ \mathrm{E}}$ in the eastern flank of the Confluence State (Kogi State) where rivers Niger and Benue converged. Kogi State is also centrally located in Nigeria otherwise known as the centre of the middle belt of the nation. The principal occupation of the people in this local government is farming on a rich gradually undulating savanna land that favours the cultivation of cereals like rice, maize and bambara nut while tubers like yam and cassava are grown.

\subsection{Sampling Techniques}

The Local Government has four districts namely: Dekina, Biraidu, Okura and Iyale/Ogbabede. Stratified random sampling was used to pick forty farmers from each stratum. In all one hundred and sixty (160) farmers were interviewed using structured questionnaire. The village extension workers were trained and used as enumerators. Secondary data on HIV infection between 2000 to 2005 were collected from the medical centres in the study areas.

Farmers' perception on HIV/AIDS disease was measured using mean score from five point Likert scale to quantify some perception variables. This scale falls under criterion group instrument whereby items were analyzed against a criterion. Each item has a weight or a score attached to it. Weights are assigned in a way that the higher the score, the more favorable the perception according to Blum and Naylor (1984). Six important statements on perception of farmers on HIV/AIDS spread (three positive and three negative to ensure fair response) were weighed as Strongly Agree (SA) $=5$ points, Agree $(A)=4$ points, undecided $(U)=3$ points Disagree $(D)=2$ points and Strongly Disagree $(S D)=1$. The average mean score was computed as follows.

Average mean score $=\quad$ Total sum of perception score

Total number of respondents 
Descriptive statistics was used to analyze information on trend of HIV/AIDS and relationship between occupation and rate of HIV/AIDS infection. A projection (forecast) of rate of HIV/AIDS infection was also made using linear regression model between 2005 to 2010 :

$$
\mathrm{y}=\mathrm{bo}+\mathrm{bix}+\mathrm{u}
$$

Where:

$\mathrm{y}=$ estimated infection level

bo $=$ constant

$\mathrm{bi}=$ coefficients

$\mathrm{x}=$ year in view (forecasted year)

$\mathrm{u}=$ error term

Thirty village extension agents were also randomly picked out of the forty extension workers in the zone. The extension workers were interviewed using structured questionnaire to know the effect of HIV/AIDS on extension work. While Descriptive statistics such as frequency and percentage were use to analyse data generated

\section{Results and Discussion}

\subsection{Perception of Farmers towards HIV/AIDS Infection}

From Table 1, a mean score of 3.88 out of a maximum score of 5, agreed with the statement that HIV/AIDS has negative effect on their health. This implies that close to eighty percent of the respondents are aware of the risk inherent in HIV/AIDS infection. These are contact farmers who interact regularly with agricultural extension workers and could have heard or shared idea on HIV/AIDS with them. It could also be as a result of the constant jingles over the radio. However, the fact that many people or farmers are aware of the risk involved in HIV/AIDS, may not stop some people from indulging in what they know can take their lives.

They believe in the statement that "Jesus (for the Christians) and Allah (for the Muslims) would protect me from HIV/AIDS infection and so there is no need for HIV/AIDS test" enjoyed a popular support of 3.25 mean score. This implies that many of the rural farmers appear to hold strongly to their belief about Jesus/Allah's protection to a level that they refused going for a test to ascertain their HIV/AIDS status. More than 50 percent (2.56 mean score) recognized that changing sexual partners is risky. This implies that more than forty percent of the respondents did not agree with the statement that exchange of sexual partners is risky. This implies that more than forty percent of the respondents did not agree with the statement that exchange of sexual partners entails any risk. These categories of farmers are prone to HIV/AIDS infection and also a source of contact/infection to others, especially in a rural community where relations can inherit widows even without knowing the HIV/AIDS status of the inherited partner.

However, mean scores of 4.13 and 3.85 were in favour of the statements that stigmatization and the scaring nature of HIV/AIDS infection respectively prevented them from willingly submitting themselves to HIV/AIDS test. This implies that more than eighty percent of the respondents have not made conscious attempt to check their HIV/AIDS status. This conforms to the findings of Fredrikson and Kanabus (2004), who reported that stigmatization, social rejection and the scaring nature of HIV/AIDS prevented some people from carrying out the HIV/AIDS tests. It also agrees with Human Development Report (HDR, 2004) who asserted that about 70 percent of infected individuals are unaware of their HIV/AIDS status. This implies that an infected individual who is unaware of his HIV/AIDS status and failed to go for HIV/AIDS test may still engage in active unprotected sexual behaviour thereby spreading the disease in multiple folds. The multiplier effect of such practice is extremely dangerous especially in a rural community with little or no health facilities. Any means that will win the psychological support of farmers to encourage them come for HIV/AIDS test should be encouraged.

The inability to go for HIV/AIDS test due to superstitious belief was however not very popular as a mean score of 1.79 has revealed.

$<$ Table 1>

\subsection{The Trend of HIV/AIDS Infections Among Farmers in the Study Area}

As presented in Table 2, the highest number of HIV/AIDS infection was recorded in the year 2001 with 50.61 percent while the least was in 2005 with 8.91 percent; other occupational groups infected with HIV/AIDS like civil servants, Artisians/Technicians and even business men could also be part-time farmers. The adverse effect of HIV/AIDS on food production should not only be seen as weakening or lowering the quality of farm labour for the full time farmers alone but even the part-time farmers. The figures indicated on the table were reported 
cases only. A high possibility exists that many victims might not have been tested to know their HIV/AIDS status. In essence, the number of HIV/AIDS victims could be far - greater than what has been recorded. However, the sharp decline in the number of HIV/AIDS victims in 2005 could be as a result of supportive services provided for HIV/AIDS victims and the effort by the government to change the behaviour of people towards all manners that could promote HIV/AIDS infections and victims.

$<$ Table 2>

\subsection{The Trend and Projection of HIV/AIDS Spread in the Rural Communities}

The result presented above has established the fact that HIV/AIDS exist in the rural communities and specifically among farmers. Negative perceptions of farmers about HIV/AIDS test and even infection can further intensify the spread of the disease. From table 3, below the HIV/AIDS trend as recorded from the Hospital also agreed with the fact that both full time and part time farmers had fallen victims of HIV/AIDS in their numbers. The quality and quantity of the labour input of the affected farmers must have dropped and as such reduced the level of food production with possible dire consequences if unabated.

A forecast or projection on the trend of HIV/AIDS using model $\mathrm{Y}=\mathrm{bo}+\mathrm{bix}+\mathrm{u}$ (Table 3) gave projected number of victim of 1,972 by year 2010. the implication of this is that as many as 1,972 persons (including farmers) all things been equal might still be living with HIV/AIDS in the local government area if the situation is not quickly reversed. Again, the contribution of about 1000 farmers to food production (farmers affected between $2000-2005$, table 2) will deteriorate in double folds by 2010, if twice of this figure exists.

$<$ Table 3>

From the trend above, as revealed by Hospital Records (2000 - 2005) one can project using

$\mathrm{Y}=\mathrm{bo}+\mathrm{bix}+\mathrm{u}$, to estimate number of HIV/AIDS infected population by 2010.where;

$\mathrm{Y}=$ estimated infected level

$\mathrm{Bo}=46823.2$

$\mathrm{Bi}=22.314$

$\mathrm{U}=0.05$

If $\mathrm{x}$ is 2010

$\mathrm{Y}=46823.2-22.314(2010)=1,972$

So estimated infected level by $2010=1,972$

\subsection{Rural Farmers Sources of Information on HIV/AIDS}

From table 4 below, about thirty percent (30\%) of the rural farmers received HIV/AIDS information from friends and relatives while 18.75 percent received information on Hiv/Aids from village health extension workers and 15.63 percent from village agricultural extension officers, which implies that both health extension workers and village agricultural extension workers are useful in the dissemination of Hiv/Aids information. It may be necessary therefore to equip the village extension workers with knowledge of Hiv/Aids preventive measures and the methodology to be disseminated to the farmers during the forth night teaching and visit training as suggested by Melude (2006)

$<$ Table $4>$

\subsection{Influence of HIV/AIDS infected farmers on agricultural extension work}

From table 5 below less than twenty percent of the village extension workers agreed that infected Hiv/Aid farmers had affected their extension work in one way or the other. Either through in ability of such farmers to participate in extension training, meetings or even the local leader's inability to come for extension, activities. This can greatly reduce farmers' information diffusion process and even innovation adoption. It is important therefore to emphasize on both formal and informal education as external intervention that would help farm families offset the effect of HIV/Aids as supported by (Pherson 2005)

$<$ Table 5>

\subsection{The Implication Of HIV/AIDS Spread In Rural Community On Agricultural Extension Work}

Some extension workers accepted that HIV/AIDS infected farmers had affected their extension activities in some ways, such as village extension training, extension meetings and even the use of local leaders. When one or two local leaders are affected with HIV/AIDS, it may reduce or negatively interfere with diffusion and adoption of 
innovation. Infected local leaders may not be active in extension programme which may lead to poor or lack of interest of some farmers who attend to extension activities through the influence of the infected local leader. It may not be easy to find another honest or reliable local leader. Continuity of extension work may be affected and as such, non adoption or discontinue adoption of farm technologies may be rampant which is definitely going to reduce food production in the country if the trend continues.

\section{Recommendations}

Whatever would appeal to the psychology of farmers to capture their attention on the need to know their HIV/AIDS status should be employed? Incentives like free HIV test, success story of farmers who are found to be HIV/AIDS positive may encourage them to be tested too.

Effort should be intensified to move from awareness level to actualizing HIV/AIDS free society through team work approach by all rural development agencies who should educate farmers on the need to be HIV/AIDS negative.

Any person who visits the health centre for whatever ailment should be tested without purposely informing the individual that he is going to be tested against HIV. Governments and donor agencies should improve on the assistance rendered by concentrating more on the establishment of comprehensive health clinics in all villages while HIV/AIDS test machines and other related health services be made free for people living in the rural areas.

\section{Conclusion}

The interlock between rural health care and agricultural production in the rural communities can be likened to Siamese twins who share the same heart and legs. The movement must go at the same time. If the popular axiom that, "a healthy nation is a wealthy nation" should be correctly used, then the presence of HIV/AIDS in our rural communities must not be allowed to destroy our wealth. Our inability to control HIV/AIDS in the rural communities will worsen the already unsatisfactory level of food production and as such unprecedented food crisis is imminent.

\section{References}

Anaeto, C.F; Nnadi, F.N, Ukpongson, Ugwuoke, F.O. and Oforka, C.I. (2008). The Level of Awareness of HIV/AIDS Among Rural Women Farmers in Nsukka Agricultural Zone - Enugu State; Implication for Extension Education. In: K.N.N. Ezike, H. Osakwe, I.G. Ekwu, C. Utobo and C.N. Mbah (eds) Agricultural Development in Nigeria: Issues and Challenges. Proceeding of the $42^{\text {nd }}$ Annual (ASN) held at the Faculty of Law Auditorium CAC Campus. Ebonyi State University, Abakaliki, Nigeria on $19^{\text {th }}-23^{\text {rd }}$ Oct. 1017-1022.

Bango, D.T. (2005). The Role of Financial Institutions in Cattle Production in Nigeria. A paper presented at the National Workshop on Improving Productivity in Cattle Farming in Nigeria, organized by the National Productivity Center, 21st $-22^{\text {nd }}$ September 2005 in Kaduna, Kaduna State, Nigeria.

Benue State Agricultural and Rural Development Authority. (BNARDA, 2003). Impact of HIV/AIDS on Rural Livelihood in Benue State; Implication for Policy Makers. Jodez Publishers Makurdi, p.2.

Blum, M.L. and J.C. Naylor. (1984). Industrial Psychology. Its Theoretical and Social Foundation, CBS Publisher and Distributor (pp 296 - 297).

Food and Agriculture Organization. (FAO, 1994). The State of Food and Agriculture - Rome.

Food and Agriculture Organization. (FAO, 2000). HIV/AIDS and Food Security; An FAO perspective - Rome.

Fredrickson,N and Kanabus S. (2004). HIV/AIDS Related stigmatization and Denial; Retrieved 15 May 2005 at www.unged co.

Human Development Report in Nigeria. (HDR, 2004). A Challenge to Substantial Development.

Ijere, M.O. (1992). Leading Issues in Rural Development. Acena Publishers, Enugu, Lagos and Los Angeles p. 13.

Melude, N.T. (2006). Capacity Building for Nigerian Agricultural Extensionist for the Dissemination of HIV/AIDS Preventive Techniques to Farm Families. Journal of Agricultural Extension, vol. 9 p. 12

Nigerian Institute of Medical Research. (NIMR. 2003). Background Document for the Training Modules on the use of Antiretroviral Drugs. Dart Ventures Nigeria p.8.

Okoro, B.O.; Ekure, K.C., Nwaobiala, C.U. and Nwakor, F.N. (2009). Strategizing Agricultural Extension Service Delivery for Enhancing Food and Livelihood Security of HIV/AIDS Affected Households in Nigeria. In: A.O. Olojede, B.C. Okoye, K.C. Ekwe, G.O. Chukwu, I.N. Nwachukwu and O. Alawode (eds). Global Food 
Crisis and Nigerian Agriculture. Proceeding of the $43^{\text {rd }}$ Annual Conference of the Agricultural Society of Nigeria (ASN) held at National Universities Commission Auditorium and RMRDC Abuja, Nigeria on $20-23^{\text {rd }}$ Oct. 630

Okoro, F.U. (1987). Change agent Role in Technological Transfer Process to Facilitate Peasant Farmers' Productivity in P.O.C. Umeh. (Ed.) Increasing Productivity in Nigeria, Proceeding of the First National Conference on Productivity National Productivity centre p. 401.

Pherson, M.E. (2005). Asset Preservation in African Agriculture in the face of HIV/AIDS. The Role of Education. American Journal of Agricultural Economics, vol. 87 No. 5 p. 1298.

Umeh, J.C. (1999). Rural and labour supplies; Empirical Evidence from the World Bank assisted Agricultural Development Project in Kwara State, Nigeria. Social Science Medicine, 12 (12): 1351 - 1360.

Table 1. Five (5) Likert Scale test on Perception of Farmers to HIV/AIDS Disease

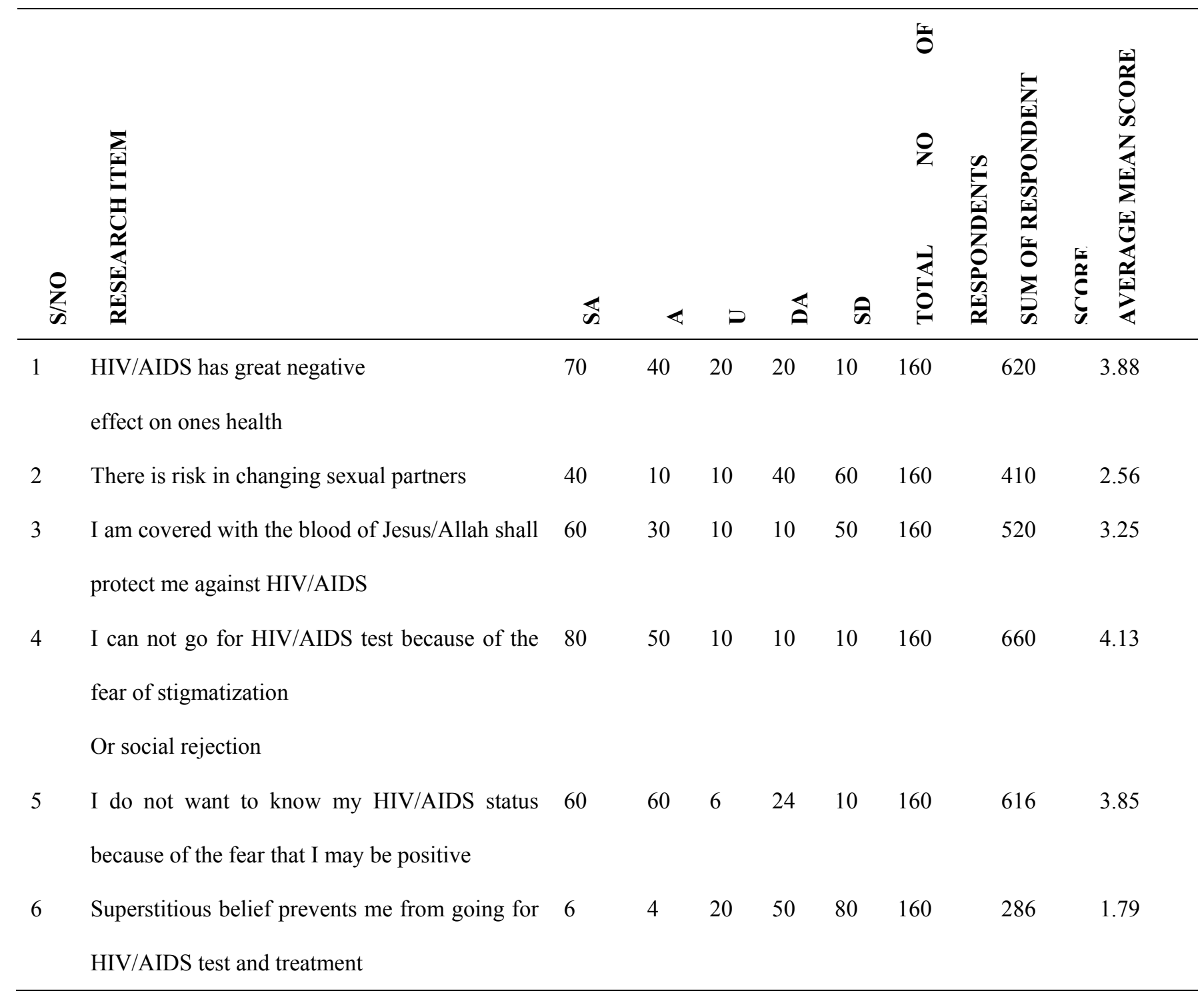

SOURCE: Field Survey 2006 
Table 2. Rate of HIV/AIDS Infection among Farmers (2000 - 2005)

\begin{tabular}{lll}
\hline YEAR & FREQUENCY & PERCENTAGE \\
\hline & & \\
2000 & 100 & 10.12 \\
2001 & 500 & 50.61 \\
2002 & 100 & 10.21 \\
2003 & 90 & 9.02 \\
2004 & 110 & 11.13 \\
2005 & 88 & 8.91 \\
Total & 988 & 100.00 \\
\hline
\end{tabular}

Source: Hospital/Health Centre Records 2000 - 2005 (field survey 2006)

Table 3. The Trend of HIV/AIDS Infection among Various Occupational Group Year

\begin{tabular}{lllllll}
\hline Occupation & $\mathbf{2 0 0 0}$ & $\mathbf{2 0 0 1}$ & $\mathbf{2 0 0 2}$ & $\mathbf{2 0 0 3}$ & $\mathbf{2 0 0 4}$ & $\mathbf{2 0 0 5}$ \\
\hline Farmers & 100 & 500 & 100 & 90 & 110 & 88 \\
Civil Servants & 180 & 250 & 299 & 251 & 205 & 100 \\
Business or Trading & 320 & 300 & 800 & 408 & 400 & 293 \\
Students & 253 & 500 & 400 & 457 & 500 & 200 \\
Technicians & 350 & 200 & 103 & 309 & 480 & 159 \\
Others & 999 & 90 & 857 & 585 & 905 & 879 \\
Total & 2202 & 1840 & 2559 & 1913 & 2600 & 1719 \\
\hline
\end{tabular}

Source: field survey 2006.

Table 4. Distribution of the respondents on sources of information on Hiv/Aids disease

\begin{tabular}{llll}
\hline S/No & Information Sources & Freq & Percentages \\
\hline 1 & Radio Jingles & 10 & 6.25 \\
2 & Friend /relative & 50 & 31.25 \\
3 & Village Agriculture Extension Worker & 25 & 15.63 \\
4 & Village Health Extension Worker & 30 & 18.75 \\
5 & Churches/Mosque & 41 & 25.62 \\
6 & Other Mass Media & 4 & 2.50 \\
& TOTAL SCORE & $\mathbf{1 6 0}$ & $\mathbf{1 0 0}$ \\
\hline
\end{tabular}

Source: field survey 2006.

Table 5. Influence of HIV/Aids infected farmers on agricultural extension work

\begin{tabular}{llll}
\hline S/No & Extension Activities & Frequency & Percentage \\
\hline 1 & Village Extension Training & 1 & 3.33 \\
2 & Contact Farmers meeting & 2 & 6.66 \\
3 & Contact Farmers response to extension work & 2 & 6.66 \\
4 & Local Leader participation on extension work & 1 & 3.33 \\
5 & Has not affected my extension work & 24 & 79.92 \\
& TOTAL SCORE & $\mathbf{3 0}$ & $\mathbf{9 9 . 9 0}$ \\
\hline
\end{tabular}

Source: field survey 2006. 